\title{
A genotypically distinct, melanic variant of Anopheles arabiensis in Sudan is associated with arid environments
}

Mariam Aboud ${ }^{1 *}$, Abdelrafie Makhawi $^{2}$, Andrea Verardi $^{3}$, Fathi El Raba'a ${ }^{4}$, Dia-Eldin Elnaiem ${ }^{5}$ and Harold Townson ${ }^{3}$

\begin{abstract}
Background: Anopheles arabiensis, an important malaria vector in Sudan and other countries in sub-Saharan Africa, exhibits considerable ecological and behavioural plasticity allowing it to survive in the harsh conditions of arid regions. It has been shown that adult populations of An. arabiensis in the semi-desert habitat of western Khartoum State survive through the long dry season in a state of partial aestivation, characterized by limited feeding activity and a degree of arrested ovarian development. Anopheles arabiensis in these sites occurs in two phenotypic forms. One is large and heavily melanized, the other has the typical characteristics of An. arabiensis as found elsewhere in Africa. The extent of genetic variation in these forms was examined in widely separated locations in Sudan, including Kassala, Gedaref and the Northern States between 1998 and 1999 and 2004 and 2006.

Methods: Each mosquito specimen was identified using standard morphological keys and a species-specific PCR test. Sequence variation in a 660 bp fragment of the mtDNA ND5 coding region was examined and the extent of genetic divergence between the forms was estimated from $F_{S T}$ values using DNASP version 4.9. TCS 1.13 software was used to determine the genealogical relationships and to reflect clustering among mtDNA haplotypes.

Results: The melanic and normal forms were found in sympatry in Kassala, Gedaref and Khartoum states, with the melanic form commonest in the hottest and most arid areas. Both forms were encountered in the periods of study: 1998-1999, and 2004-2006. Only ten specimens of An. arabiensis were collected from the Northern State in February 2006, all of which were of the normal form.

Based on the ND5 analysis, there was a marked subdivision between the normal and melanic forms $\left(F_{S T}=0.59\right)$.

Furthermore, the melanic form showed more genetic variability, as measured by haplotype diversity (0.95) compared with the normal form (0.57), suggesting larger effective population.
\end{abstract}

Conclusions: This is the first demonstration of correspondent phenotypic and genetic structuring in An. arabiensis. The high level of genetic differentiation shown by the mtDNA ND5 locus suggests that the two forms may represent separate species. It is hypothesized that the melanic form is better adapted to hot and arid environments.

Keywords: Anopheles arabiensis, ND5, Sudan, Melanic, Malaria, Arid environments

\footnotetext{
* Correspondence: mariamaboud99@gmail.com

'Department of Biology, Faculty of Science and Technology, Al-Neelain

University, Khartoum, Sudan

Full list of author information is available at the end of the article
} 


\section{Background}

The main groups of malaria vectors in Africa are Anopheles gambiae, Anopheles funestus, Anopheles nili and Anopheles moucheti. Each of these comprise a complex or group of genetically distinct species that are similar in morphology, but vary in traits that affect their role in transmission of malaria [1-3]. The most important of these groups is the An. gambiae complex, which comprises eight closely related species that are distributed through subSaharan Africa and its outer islands [4-7]. Within this complex, An. gambiae, Anopheles coluzzii and Anopheles arabiensis are the most efficient vectors of human malaria in Africa $[5,8,9]$.

Anopheles arabiensis is a common malaria vector throughout sub-Saharan Africa [10-12]. This species shows considerable ecological and behavioural plasticity that allows it to survive in the harsh conditions of some arid areas. Some studies have indicated that An. arabiensis may be replacing An. gambiae s.s. as the dominant malaria vector in areas of East Africa, where insecticide-impregnated nets are used intensively [13,14]. Different geographical populations of $A n$. arabiensis show marked variations in their anthropophilic, exophilic and exophagic behaviour; thus adding more complexity to malaria transmission, and ultimately malaria control [15-19]. However, studies using a number of molecular markers, including partial mitochondrial gene sequences from the cytochrome b, ND1 and ND5 genes, microsatellite loci, chromosomal inversions and internal transcribed spacers 1 and 2 (ITS1 \& ITS2) showed little population subdivision within $A n$. arabiensis populations, as compared to An. gambiae s.s. [20-35]. This low level of population differentiation across the range of $A n$. arabiensis populations has been attributed to recent population range expansion $[28,29]$.

In contrast, strong genetic differentiation in mtDNA (ND5) was detected between allopatric populations of $A n$. arabiensis from the island of Reunion and the African continent, which was attributed to the low effective population size $(\mathrm{Ne})$ on the island [32]. Lee et al. [36] reported a fixed nucleotide on the $\mathrm{X}$ chromosome between populations in East-southern Africa and those in Central Africa.

Anopheles arabiensis is the primary malaria vector throughout much of Sudan [37]. Other Anopheles species, such as An. funestus, An. nili, Anopheles pharoensis, Anopheles rufipes and Anopheles dthali are also present in the country, but they play a negligible role in malaria transmission. Malaria transmitted by $A n$. arabiensis, continues to be a major health problem in Sudan [38,39]. It has long been postulated that populations of $A n$. arabiensis undergo aestivation during the dry season $[40,41]$. It has been suggested that adults of a local population of An. arabiensis, in semi-desert habitat in Khartoum state (Sudan) are highly adapted to survive through the harsh long dry season, in a state of partial aestivation "with limited feeding activities and a degree of arrested ovarian development". Similar findings were recently reported for An. gambiae and $A n$. coluzzii (formerly $\mathrm{S}$ and $\mathrm{M}$ molecular forms) in Mali [42-46]. Interestingly, these studies showed that whereas aestivation is a dry season survival strategy used by the $M$ form of An. gambiae, populations of An. arabiensis and the $\mathrm{S}$ form of $A n$. gambiae from the same area are more likely to rely on migration from distant locations [43].

It is hypothesized that the persistence of An. arabiensis populations in the arid areas in Khartoum State may be reflected in the genetic structure of these populations. To test this hypothesis, a molecular study was conducted on adults of An. arabiensis collected from irrigated sites along the White Nile and from an arid region, West of Khartoum, where previous studies showed the presence of aestivating adults of this species [40]. In these regions adults of $A n$. arabiensis occur in two phenotypic forms, distinguishable by their size and extent of melanization.

\section{Methods and study sites}

Mosquito adult samples were collected from irrigated and non-irrigated habitats in Khartoum State (Central Sudan), Gedaref State (eastern Sudan), Kassala State (eastern Sudan) and Northern State. These locations are characterized by marked variations in rain precipitation and malaria endemicity (Figure 1 and Table 1). Whereas Gedaref and Kassala States are in the zone of hyperendemic malaria, Khartoum and Northern states are considered to be hypo-, meso-endemic or zones free from malaria, respectively [39].

\section{Khartoum state}

Located in central Sudan, at the confluence of the White Nile and the Blue Nile, $\left(15^{\circ} 30^{\prime}-15^{\circ} 45^{\prime} \mathrm{N}\right.$ and $\left.32^{\circ} 15^{\prime}-32^{\circ} 45^{\prime} \mathrm{E}\right)$, Khartoum State is characterized by a long dry and hot season between October - June followed by a short rainy season (July - September) with an average annual precipitation of $240 \mathrm{~mm}$. Khartoum State has poor dry desert scrub vegetation, except along the riverbanks and in irrigated agricultural schemes. Sites used for collection of mosquitoes in Khartoum State were dry nonirrigated areas and irrigated areas close to the Nile, White Nile and the Blue Nile. Mosquito samples were collected between December 2004 and November 2006 in three villages in western Omdurman: El Mowailih (dry, $15^{\circ} 34^{\prime}$ $\mathrm{N}-32^{\circ} 23^{\prime} \mathrm{E}$ ), El Rawakeeb (very dry $15^{\circ} 30^{\prime} \mathrm{N}-32^{\circ} 15^{\prime} \mathrm{E}$ ) and $\mathrm{El}$ Teris (irrigated $15^{\circ} 23^{\prime} \mathrm{N}-32^{\circ} 48^{\prime} \mathrm{E}$ ).

\section{Gedaref state}

This State extends over large areas in the savannah region of Eastern Sudan. The climate is a tropical continental climate with two seasons; rainy season lasting from JuneOctober and dry season between November to May with an average min-max temperature of $34-40^{\circ} \mathrm{C}$. The average 


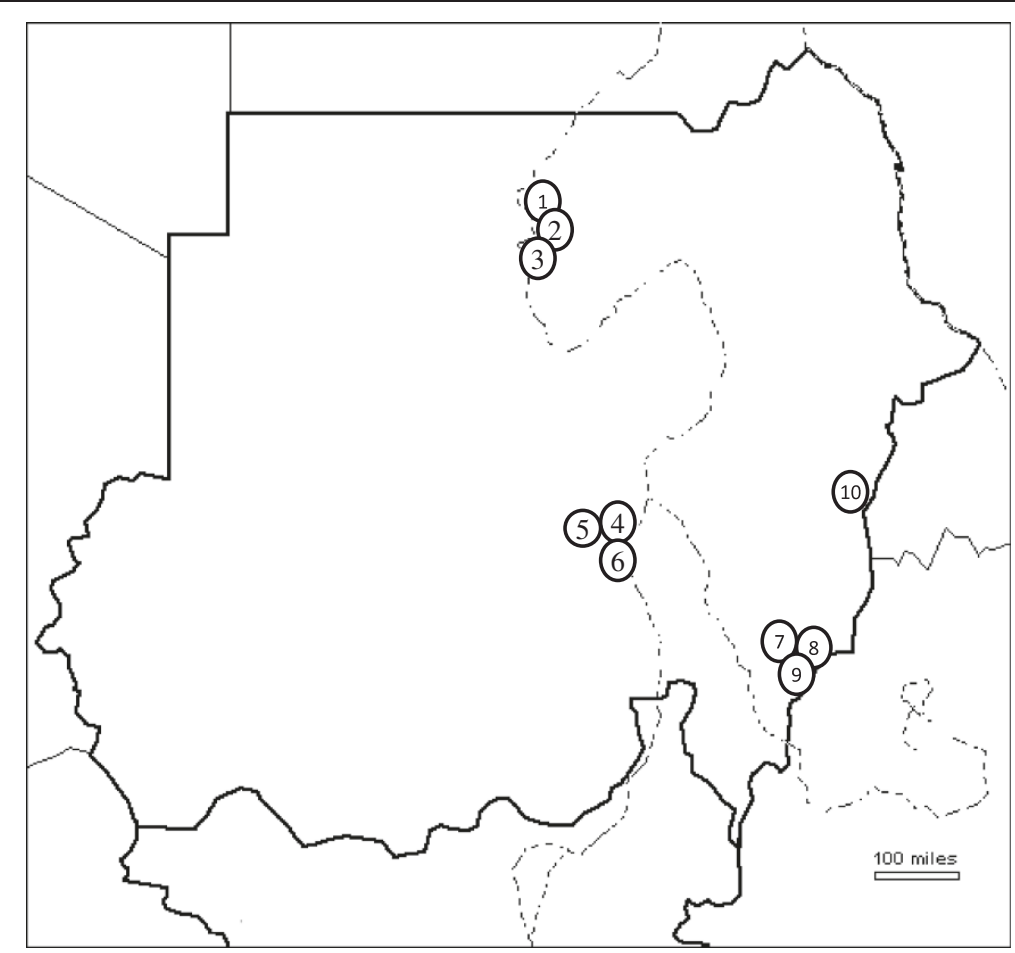

Figure 1 Map of Sudan showing sampling sites collection of Anopheles arabiensis. North State (sites 1,2 \& 3); Khartoum (sites 4,5\&6); Gedaref (sites 7,8\&9) and Kassala (site 10).

annual rainfall is $815 \mathrm{~mm}$. Mosquito samples were collected during December 2004 and November 2006 in three villages in Rahad province: Batta (12 $\left.53^{\prime} \mathrm{N}-35^{\circ} 7^{\prime} \mathrm{E}\right)$, Kuka $\left(13^{\circ} 06^{\prime} \mathrm{N}-34^{\circ} 57^{\prime} \mathrm{E}\right)$ and Tabaldia $\left(12^{\circ} 53^{\prime} \mathrm{N}-35^{\circ} 9^{\prime} \mathrm{E}\right)$. These villages lie along eastern bank of the El Rahad River, which is a seasonal watercourse that flows during and after the rainy season, June - December. Thereafter it fragments into small water pools during the dry hot season. Gedaref State is characterized with rich vegetation, especially during the rainy season. The main trees and bushes found in the study area are Balanites aegyptiaca, Acacia seyal, Acacia mellifera, Acacia nilotica, Acacia senegal, Combretum spp., Azadirachta indica and Ziziphus spina-christi. In the most of the places, the surface of the ground covered by Sorghum spp., Schoenfeldia ssp., Cynodon spp., Aristida spp., Cinchrus spp., and Brachiara spp. grass, which flourishes during the rainy and post-rainy season and dies out during the dry season.

\section{Kassala state}

Kassala State lies about $611 \mathrm{~km}$ East of Khartoum, at the edge of the semi-desert region of eastern Sudan, Gedaref State from the South and close to the border with Eritrea. The climate of the area is characterized by a hot dry season, which extends from March-June followed by a short rainy season (June - October) with an average annual rainfall of $400 \mathrm{~mm}$. The vegetation of Kassala is similar to that found in Gadaref State, but with a lower

Table 1 Sites, dates and sampling methods of adult mosquitoes used in study of genetic and morphometric differentiation of Anopheles arabiensis in Sudan 1998-2001 and 2004-2006

\begin{tabular}{|c|c|c|c|c|c|c|}
\hline Location & Position & $\begin{array}{l}\text { Malaria } \\
\text { endemicity }\end{array}$ & $\begin{array}{l}\text { Rainy } \\
\text { season }\end{array}$ & $\begin{array}{l}\text { Rain } \\
\text { precipitate }\end{array}$ & Sampling date & Sampling methods \\
\hline Khartoum & $\begin{array}{l}15^{\circ} 3^{\prime}-15^{\circ} 45^{\prime} N 32^{\circ} \\
15^{\prime}-32^{\circ} 45^{\prime} \mathrm{E}\end{array}$ & $\begin{array}{l}\text { hypo-meso } \\
\text { endemic }\end{array}$ & July -September & $240 \mathrm{~mm}$ & $\begin{array}{l}\text { Nov } 1998 \text { - Oct 1999, July } \\
\text { 2001, Dec } 2004 \text { - Nov } 2006\end{array}$ & $\begin{array}{l}\text { Pyrethrum spray collection, Landing } \\
\text { collection, Active search }\end{array}$ \\
\hline Gedaref & $12^{\circ} 54^{\prime} \mathrm{N} 35^{\circ} 08^{\prime} \mathrm{E}$ & hyper-endemic & June -October & $815 \mathrm{~mm}$ & Dec 2004 and Nov 2006 & $\begin{array}{l}\text { Pyrethrum spray collection, Landing } \\
\text { collection, Active search }\end{array}$ \\
\hline Kassala & $15^{\circ} 22 \mathrm{~N}^{\prime} 36^{\circ} 27^{\prime} \mathrm{E}$ & hyper-endemic & June -October & $400 \mathrm{~mm}$ & March 2005 and April 2006 & $\begin{array}{l}\text { Pyrethrum spray collection, Landing } \\
\text { collection, Active search }\end{array}$ \\
\hline North & $19^{\circ} 16 \mathrm{~N}^{\prime} 0^{\circ} 27^{\prime} \mathrm{E}$ & free zones of malaria & September & $1 \mathrm{~mm}$ & Feb 2006 & $\begin{array}{l}\text { Pyrethrum spray collection, Landing } \\
\text { collection, Active search }\end{array}$ \\
\hline
\end{tabular}


vegetation density. Mosquito samples were collected during March 2005 and April 2006 from Wad Sherifi village $\left(15^{\circ} 22^{\prime} \mathrm{N}-36^{\circ} 27^{\prime} \mathrm{E}\right)$. The only source of water is well-water storage tank.

\section{Northern state}

Located in the northwest corner of Sudan bordering Egypt and Libya, the Northern State is an extremely dry desert, intercepted by a narrow stretch of seasonally flooded and irrigated areas around the Nile. Rainfall rarely exceeds an average of $1 \mathrm{~mm}$ per annum, in most years and the vegetation ranges from true desert to semi-desert scrub. Daily maximum temperatures are generally high reaching $47^{\circ} \mathrm{C}$ beween May and August, with desert temperatures cool at night, and a minimum temperature of c. $25-29^{\circ} \mathrm{C}$.

Morphological and molecular identification of mosquitoes Mosquitoes were identified morphologically using standard taxonomic keys $[47,48]$.

Since the only An. gambiae s.l. species found in the study areas is An. arabiensis, these taxonomic keys provided a sufficient tool for species identification. In order to confirm the identification of the An. gambiae complex to species level, a molecular diagnostic test was performed using the rDNA species-diagnostic PCR protocol [49] protocol. DNA was extracted from individual mosquitoes using a previously described method [50].

\section{Amplification and sequencing of a mitochondrial DNA fragment}

To study molecular variation of An. arabiensis populations, a 655 bp fragment of the mitochondrial nicotinamide adenine dinucleotide dehydrogenase gene subunit 5 (NADH-ND5) coding region sequences of mitochondrial DNA was PCR amplified as previously described [20]. The PCR mix comprised $50 \mu \mathrm{l}$ reaction volume containing $1 \mu \mathrm{L}$ of 1:200 DNA dilution, 50 pmol primers, DMP3A = 5'-AGG ATG AGA TGG CTT AGG TT-3'; 19CL=5'CTT CCA CCA ATT ACT GCT ATA ACA G-3'. The PCR product was purified using QIAquick PCR purification Kit (QIAGEN). The purified PCR product and cycle sequencing was performed with the ABI PRISM Dye Terminator Cycle Sequencing Kit (Applied Biosystems). DNA sequences were assembled, and analysis of nucleotide sequences was performed using an ABI PRISM 377 (Applied Biosystems) automated sequencer following the manufacturer's protocols. All sequences were deposited in NCBI GenBank (accession numbers KJ950294-KJ950360).

\section{Mitochondrial ND5 DNA analysis}

Prior to analysis, the $655 \mathrm{bp}$ fragment of mtDNA (ND5) was confirmed by blasting against the corresponding $A n$. gambiae sequence ([51]; GeneBank accession No. L20934). Subsequently, ND5 sequences from individual mosquitoes were aligned using the Clustal W programme and subjected to genetic variation analysis. The frequency of each haplotype, haplotype diversity $(\mathrm{Hd})$, average number of pairwise nucleotide differences $(\pi)$ and average number of nucleotides segregating per site $(\mathrm{S})$, the population mutation rate $(2 \mathrm{~N} M)$ based on number of segregating sites $(\theta)$ were computed using the program DnaSP version 4.9 [52]. Sequences of ND5 were tested for neutral evolution, using Tajima's D test [53] and Fu \& Li's F tests [54]. The extent of nucleotide differentiation between An. arabiensis populations was calculated by estimating $\mathrm{F}_{\mathrm{ST}}$ values.

\section{Gene genealogy network}

TCS 1.13[55] was used to determine the genealogical relationships and inspect clustering among mtND5 haplotypes. This method is based on statistical parsimony network [56], and was chosen because it accepts the existence of ancestral haplotypes, which are assumed to be the most frequent haplotypes, according to coalescence theory [57].

\section{Results}

Although all specimens used in the study were morphologically and molecularly typed as An. arabiensis, two phenotypic forms of An. arabiensis were recognizable. One of these forms was larger, markedly darker and more metallic in colour than the other, which appeared as typical An. arabiensis. These forms are here labelled as the melanic $(\mathrm{M})$ and normal $(\mathrm{N})$ forms, respectively; all specimens were labelled accordingly.

Adult specimens of An. arabiensis were easily assigned to one of the two forms and no intermediate phenotypes were observed. The difference in body size was noticeable and measured. The body size of the adult melanic form was clearly larger than the normal form (mean body size and wing length $=3.25 \pm 0.22 \mathrm{~mm}$ and $2.68 \pm 0.078$ for the melanic form and $2.71 \pm 0.19 \mathrm{~mm}$ and $2.37 \pm 0.09 \mathrm{~mm}$ for the normal form, respectively). Both melanization and body size appeared to be inheritable characters. In colonization experiments, both forms produced corresponding adult offspring. The spatial distribution of normal and melanic forms in the different sites in Khartoum State is shown in Table 2. It is clear that the melanic form occurred more commonly in the hottest and most arid areas than in the irrigated areas (Tables 2 and 3, and Additional file 1).

\section{Haplotype diversity and genetic variation in the mtND5 of Anopheles arabiensis}

Genetic variation in the populations of An. arabiensis was studied by examining variation in a 655 bp (position 68967550) fragment of the mtND5 gene of An. gambiae [51], for a total of 232 An. arabiensis samples spanning the four study areas. Reference sequences have been deposited in GeneBank (accession numbers KJ950294-KJ950360). All 
Table 2 Spatial and season distribution of melanic and normal forms of An. arabiensis collected form Khartoum State (Sudan) in 1998-1999 and 2004-2006

\begin{tabular}{llllll}
\hline Study area & Form & $\begin{array}{l}\text { Dry season } \\
\text { (Oct 1998-June 1999) }\end{array}$ & $\begin{array}{l}\text { Rainy season } \\
\text { (Jul-Sep 1998) }\end{array}$ & $\begin{array}{l}\text { Dry season } \\
\text { (Oct-2004-Jun-2005) }\end{array}$ & $\begin{array}{l}\text { Rainy season } \\
\text { (July-Sep 2005) }\end{array}$ \\
\hline El Tries (Irrigated) & Normal & $118(92.9 \%)$ & $241(97.6 \%)$ & $230(94.3 \%)$ & $67(78.8 \%)$ \\
& Melanic & $9(7.1 \%)$ & $6(2.4 \%)$ & $14(5.7 \%)$ & $18(21.2 \%)$ \\
& Total & 127 & 247 & 244 & 85 \\
El Mowailih (Dry-irrigated) & Normal & $49(41.2)$ & $312(75.7 \%)$ & $42(16.1)$ & $208(66.5 \%)$ \\
& Melanic & $70(57.8)$ & $100(24.3 \%$ & $219(83.9)$ & $105(33.5 \%)$ \\
& Total & 119 & 412 & 261 & 313 \\
Elrawakeeb (Very dry) & Normal & - & - & - & $2(6.9 \%)$ \\
& Melanic & - & - & - & $27(93.1 \%)$ \\
& Total & - & - & - & 29 \\
\hline
\end{tabular}

polymorphic sites were silent codon sites and the direct sequencing revealed no characteristics of heteroplasmy. No insertion and deletion differences were found within any mtDNA sequences, confirming that the sequenced segment of ND5 gene represented mtDNA rather than pseudo genes or nuclear-transposed copies.

The results of Tajima's D test [51] and Fu \& Li's F tests [54] on ND5 gene sequences of all An. arabiensis individuals examined in this study are shown in Table 4. Significant departure from the neutral theory was noticeable in each population of the melanic and normal forms, except in Kassala area. The deviation was higher in the normal form, indicating higher selection pressure in the melanic form.

A total of 67 mtDNA haplotypes were found among 232 An. arabiensis individuals, 35 of which represented

Table 3 Site and habitat description of melanic and normal forms of An. arabiensis populations collected in different localities of Sudan in 1999-2000 and 2004-2006

\begin{tabular}{|c|c|c|c|c|c|}
\hline Location & $\begin{array}{l}\text { Habitat } \\
\text { Type }\end{array}$ & $\begin{array}{l}\text { Main water } \\
\text { source }\end{array}$ & Breeding sites & $\begin{array}{l}\text { Normal } \\
\text { haplotype }\end{array}$ & Melanic haplotype \\
\hline \multicolumn{6}{|l|}{ Khartoum } \\
\hline El Mowailih & Dry & Well- pumped closed tanks & Water leaking from Well-water tanks & $1(19), 2,6,9,12$ & $\begin{array}{l}18(3), 19,21,24,26(2) 27(3), 34(2) \\
36(2), 39(2), 40,48,49,51,52(2) \\
53(3), 54(2), 57(3), 60,61 \\
65(2), 66(3), 67(4)\end{array}$ \\
\hline El Rawakeeb & Very Dry & $\begin{array}{l}\text { Old wells and Well-pumped } \\
\text { closed tanks }\end{array}$ & $\begin{array}{l}\text { No water pools due to Sandy } \\
\text { soil, and high rate of evaporation, } \\
\text { Probably breeding in old wells }\end{array}$ & $1(5), 7(5), 12(2)$ & $29,31,47,53(4), 56,60,67(3)$ \\
\hline El Tries & Irrigated & White Nile & $\begin{array}{l}\text { Flooded irrigated canals from } \\
\text { White Nile }\end{array}$ & $1(8), 7$ & $\begin{array}{l}20,28,30,38(2), 50,52,53,55 \\
58,63,67(3)\end{array}$ \\
\hline Others & Irrigated & Nile, White Nile and Blue Nile & $\begin{array}{l}\text { Flooded irrigated canals from } \\
\text { Nile, White Nile and Blue Nile }\end{array}$ & $1(3), 8,12(2), 15(2), 17(2)$ & $23,25,30$ \\
\hline \multicolumn{6}{|l|}{ Gedaref } \\
\hline Bata & Semi dry & River, River pools, & Rain pools and river pools & $1(4)$ & $33,66,67(2)$ \\
\hline Kuka & irrigated & River, River pools & Rain pools and river pools & $1(3)$ & $19,21,46,67(2)$ \\
\hline Tabaldia & Semi dry & River, River pools & Rain pools and river pools & $1(6), 3,7,11,12(2), 16$ & $\begin{array}{l}18(3), 20,21,22,32,44,45(2) \\
61(2), 67(3)\end{array}$ \\
\hline \multicolumn{6}{|l|}{ Kassala } \\
\hline WadSharefi & Dry & Wells and Well-pumped tanks & Water leaking from ell-water tanks & $1(15) 3,4,5,7,8,13,14,16(2)$ & $\begin{array}{l}20,21,22,29,35,36,37(2) 41 \\
42,43,46,57(4), 59,61,62,64 \\
66(3), 67(9)\end{array}$ \\
\hline \multicolumn{6}{|l|}{ North } \\
\hline Ardwan & Irrigated & Nile River & Flooded irrigated canals rom Nile & $1(2), 7$ & No melanic haplotype \\
\hline ElSeleim & Irrigated & Nile River & Flooded irrigated canals from Nile & $1(3), 7(2)$ & No melanic haplotype \\
\hline Sadiac & Irrigated & Nile River & Flooded irrigated canals from Nile & 1,7 & No melanic haplotype \\
\hline
\end{tabular}


Table 4 Haplotypes and nucleotide diversity of mtND5 within melanic and normal forms of An. arabiensis populations collected from different sites in Sudan during 1998-2001 and 2004-2006

\begin{tabular}{|c|c|c|c|c|c|c|c|c|c|c|}
\hline Location & Form & $\mathrm{N}$ & $S$ & $\mathrm{H}$ & $\mathrm{Hd}$ & $\pi_{\mathrm{nd}}$ & $\theta_{s}$ & $\theta$ & Taji ma D & Fu \&Li \\
\hline \multirow[t]{3}{*}{ Khartoum } & Normal & 53 & 8 & 9 & $0.573(0.076)$ & $0.00127(0.00024)$ & 0.00303 & -1.3213 & -1.6101 & -1.6681 \\
\hline & Melanic & 69 & 29 & 35 & $0.959(0.028)$ & $0.00514(0.0003)$ & 0.0099 & -1.0686 & -1.5263 & -1.5681 \\
\hline & All & 122 & 33 & 44 & $0.907(0.021)$ & $0.0057(0.00024)$ & 0.0099 & $-2.6336^{*}$ & -1.3054 & $-2.5164^{*}$ \\
\hline \multirow[t]{5}{*}{ Gadaref } & Normal & 19 & 6 & 6 & $0.538(0.133)$ & $0.0011(0.00036)$ & 0.0026 & -2.205 & $-1.8697^{*}$ & -2.4356 \\
\hline & Melanic & 24 & 17 & 13 & 0.902 & $0.00547(0.00056)$ & 0.0069 & -1.0686 & -0.7632 & -1.1399 \\
\hline & & & & & 0.046 & & & & & \\
\hline & All & 43 & 21 & 19 & $0.883(0.037)$ & 0.00554 & 0.0078 & -1.8960 & -0.9456 & -1.863 \\
\hline & & & & & & 0.00041 & & & & \\
\hline \multirow[t]{3}{*}{ Kassala } & Normal & 25 & 9 & 10 & $0.647(0.110)$ & $0.00133(0.00032)$ & 0.0040 & $-3.184^{* *}$ & $-2.2181^{* *}$ & $-3.738^{* *}$ \\
\hline & Melanic & 32 & 24 & 18 & $0.907(0.039)$ & $0.00488(0.0007)$ & 0.0095 & -2.277 & -1.7072 & -2.4653 \\
\hline & All & 57 & 32 & 28 & $0.905(0.028)$ & $0.0062(0.00035)$ & 0.00113 & $-2.908^{*}$ & -1.4739 & $-2.8434^{*}$ \\
\hline \multirow[t]{2}{*}{ North } & Normal & 10 & 1 & 2 & $0.556(0.075)$ & $0.00085(0.00011)$ & 0.0054 & 0.8042 & 0.8042 & 1.0688 \\
\hline & Melanic & none & none & none & none & none & none & none & none & none \\
\hline \multirow[t]{3}{*}{ Overall } & Normal & 107 & 17 & 17 & $0.591(0.054)$ & $0.00126(0.00017)$ & 0.00524 & $-3.1767^{*}$ & $-2.1472^{*}$ & $-3.3358^{*}$ \\
\hline & Melanic & 125 & 39 & 50 & $0.943(0.014)$ & $0.0052(0.0003)$ & 0.0122 & -2.1426 & -1.7545 & $-2.3809^{*}$ \\
\hline & All & 232 & 50 & 67 & $0.897(0.016)$ & $0.0057(0.00018)$ & 0.00137 & $-3.1918^{*}$ & -1.71937 & $-3.0457^{* *}$ \\
\hline
\end{tabular}

$\mathrm{n}$, the number of sequences; $\mathrm{S}$, the number of segregating sites; $h$, number of haplotypes; $\mathrm{Hd}$, haplotypes diversity; $\pi$, the average number of pairwise nucleotide differences ((nucleotide diversity); $\theta$ s the average number of nucleotides segregating per site, $\theta=$ Average number of mutation per sequence. Values in parentheses are SE. ${ }^{* *} \mathrm{P}>0.1 ;{ }^{*} 0.10>\mathrm{P}>0.05$.

a single individual (see Additional file 1). The melanic form differed from the normal form by the presence of one or more of the substitutions A,C,T,G that consisted of four substitutions in positions 7240 (A substitute G), 7360 (C substitute T), 7486 (T substitute C) and 7627 (G substitute A). Of these four sites, the main substitution that differentiated all normal haplotypes from the melanic form was the first G/A substitution in position 7240. High levels of mtDNA ND5 haplotype diversity and nucleotide sequence divergence were encountered between allopatric and sympatric populations of the normal and melanic forms of An. arabiensis populations in Khartoum, Gedaref and Kassala States (Table 4).

It was clear that, in each location, the haplotype diversity within melanic populations of An. arabiensis was higher than within normal populations and almost equal to the overall haplotype diversity of the two forms. This result is consistent with a smaller effective population size of the normal form. In North State, where the analysis was restricted to a small number of the normal form (10 specimens), the haplotype and nucleotide diversity of $A$. arabiensis population were 0.56 $(\mathrm{P} \leq 0.001)$ and $0.00085(\mathrm{P} \leq 0.001)$, respectively.

The data provide clear evidence of corresponding morphological and genetic structuring in populations of $A n$. arabiensis in sympatry. The average level of mtDNA ND5 sequence divergence within Sudanese An. arabiensis populations is $0.57 \%( \pm 0.0002)$ (Table 4$)$. This strong population subdivision within $A n$. arabiensis populations was also supported by the $\mathrm{F}_{\mathrm{ST}}$ value of $0.59(\mathrm{P} \leq 0.0001)$ between normal and melanic forms. This provides strong evidence for limited gene exchange $(\mathrm{Nm}=0.36)$ between melanic and normal forms of An. arabiensis, even though the forms are sympatric (Table 5).

\section{Mitochondrial ND5 genealogy estimation}

In the Templeton network (Figure 2), the sequence data of mtND5 for An. arabiensis populations segregated into two major groups in addition to the minor varieties. Those two major groups of haplotypes correspond closely to the phenotypic variation detected within An. arabiensis populations, i.e. melanic and normal forms.

\section{Discussion}

The findings obtained in this study provide first evidence of correspondent morphological and genetic population structuring in $A n$. arabiensis that exist in sympatry. These results contradict the current notion that An. arabiensis populations in sub-Saharan Africa are panmictic [19,20,24,26-31,33,34,58]. Using relevant keys [47,48] and species-diagnostic PCR method [49], all mosquitoes used in the study were morphologically and molecularly confirmed as An. arabiensis. However, two clearly distinguishable phenotypic forms were found: a typical normal colour-size form and a larger heavily melanized form. Furthermore, our observations lead us to hypothesize that the melanic form is more adapted to arid hot environment, as deduced from relative higher abundance and 
Table 5 Genetic differentiation $\left(F_{S T}\right)$ and Gene flow $(\mathrm{Nm})$ between normal and melanic forms of sympatric and allopatric populations of An. arabiensis captured in different localities in Sudan in 1999-2000 and 2004-2006

\begin{tabular}{|c|c|c|c|c|c|}
\hline \multirow[t]{2}{*}{ State } & \multirow{2}{*}{$\begin{array}{l}\text { Sympatric } \\
\text { populations } \\
\text { Fst }(\mathrm{Nm})\end{array}$} & \multicolumn{4}{|c|}{ Allopatric populations } \\
\hline & & State & $\begin{array}{l}\text { Normal V melanic } \\
\text { Fst }(\mathrm{Nm})\end{array}$ & $\begin{array}{l}\text { Normal V Normal } \\
\text { Fst }(\mathrm{Nm})\end{array}$ & $\begin{array}{l}\text { Melanic v Melanic } \\
\text { Fst }(\mathrm{Nm})\end{array}$ \\
\hline \multirow[t]{2}{*}{ Khartoum } & $0.58(0.36)$ & Khartoum V Kassala & $0.635(0.29)$ & $0.028(17.26)$ & $0.0313(15.62)$ \\
\hline & $(0.0000)^{*}$ & & $(0.0000)^{*}$ & $(0.0655)^{\mathrm{ns}}$ & $(0.1454)^{\mathrm{ns}}$ \\
\hline \multirow[t]{2}{*}{ Kassala } & $0.65(0.27)$ & Khartoum V Gedaref & $0.597(0.34)$ & $0.0027(185.5)$ & $0.01095(45.2)$ \\
\hline & $(0.0006)^{*}$ & & $(0.0000)^{*}$ & $(0.377)^{\mathrm{ns}}$ & $(0.1921)^{\mathrm{ns}}$ \\
\hline \multirow[t]{2}{*}{ Gedaref } & $0.546(0.42)$ & Kassala V Gedaref & $0.55(0.41)$ & $0.0157(32.4)$ & $0.022(22.1)$ \\
\hline & $(0.0008)^{*}$ & & $(0.0008)^{*}$ & $(0.6383)^{\mathrm{ns}}$ & $(0.3355)^{\mathrm{ns}}$ \\
\hline
\end{tabular}

ns, not significant; ${ }^{*} \mathrm{P} \leq 0.001$.

larger effective population size. This adaptation may have been conferred by the increased level of melanization, which is known to provide protection against desiccation [59-63].

From a molecular viewpoint, the normal form is identical to An. arabiensis type form based on colour and mtND5 sequence. The mtND5 gene of the melanic form is different from An. arabiensis type form by up to four nucleotide substitutions (one apparently fixed and three other variable nucleotide substitutions), although these forms are sympatric in different collection sites. These nucleotide substitutions, which were found in melanic form, are similar to those found in An. arabiensis populations in Senegal [20].

The average level of mtDNA ND5 sequence divergence within Sudanese An. arabiensis populations (0.57\%) is higher than the average level of mtND5 sequence divergence within An. gambiae $(0.38 \%)$ and An. arabiensis $(0.46 \%)$ populations across Africa [20]. Moreover, the average level of mtDNA ND5 divergence between species (An. gambiae and An. arabiensis) was only $0.46 \%$ per nucleotide.

The $\mathrm{F}_{\mathrm{ST}}$ value between sympatric populations of melanic and normal forms of An. arabiensis is significantly higher than previous $\mathrm{F}_{\mathrm{ST}}$ pairwise studies of the same

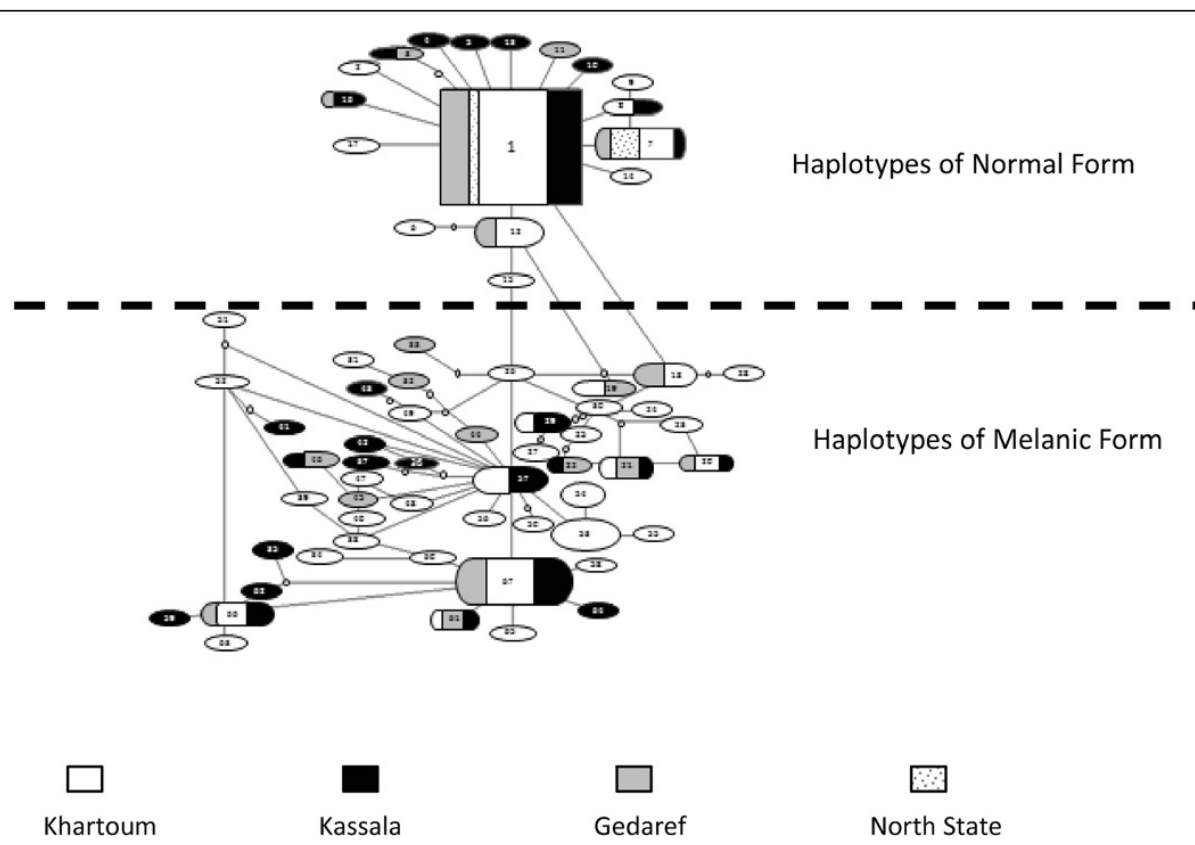

Figure 2 Genealogical haplotype network analysis for a $655 \mathrm{bp}$ fragment of ND5 of An. arabiensis in Sudan using the statistical parsimony method implemented in TCS (Clement et al. [55]). Localities where haplotypes were found are represented by different fill patterns, as shown in the legend. Haplotype with the highest outgroup probability is displayed as rectangle and are assumed to be ancestral; other haplotypes are displayed as ovals. Haplotype symbol sizes correspond to frequencies; nodes without haplotype numbers correspond to assumed intermediates. Haplotypes number 1-17 represent a normal form of An. arabiensis and haplotypes number 18-67 represent melanic form of An. arabiensis. 
gene in An. gambiae and An. arabiensis populations in Africa, and other pairs of sibling species of Anopheles $[20,32,36,64]$. Moreover, intraspecific estimates of genetic differentiation $\left(\mathrm{F}_{\mathrm{ST}}\right)$ within $A n$. arabiensis populations were low (0.098) comparable to the interspecific $\mathrm{F}_{\mathrm{ST}}$ estimates between An. arabiensis and An. gambiae, which were recorded as 0.07 and 0.12 for sympatric and allopatric populations, respectively [32].

The failure to find the melanic form in Northern State may be a consequence of the small sample size, or ecological separation due to the highly restrictive habitats of An. arabiensis in this area. Elsewhere in this study, the two forms were found in sympatry suggesting that there is a strong level of reproductive isolation between them. In this part of Sudan, where no rain may fall for several years, there is a sharp contrast between extreme desert conditions and irrigated areas along the Nile. The only suitable breeding and resting sites for An. arabiensis exist in agricultural schemes along the Nile or the ponds created by the seasonal flood in agricultural schemes. On the other hand away from the Nile there is no possibility of temporary mosquito breeding and resting sites due to lack of vegetation, extreme aridity and sandy soil topography of the area and in addition lack of wellpumped tanks. The few specimens of An. arabiensis collected in this study were captured during a short visit focusing on the irrigated area, where permanent breeding sites are present. Future studies should survey the area for possible presence of the habitat of the melanic form.

In dry areas of Khartoum and Kassala there is no surface water. The villagers obtain their water from a number of scattered water tanks which pumps water from capped wells. There are number of small scattered farms of sorghum around each water tank. Anopheles arabiensis populations breed in temporary breeding sites available from continuous leaking of water from these water tanks. The establishment of these well-pump tanks - which is the only available source of water for the villager's uses - may serve as temporary breeding and resting sites for An. arabiensis in dry zone areas throughout the year. In Gedaref State, the study sites lie along eastern bank of El Rahad River, which is a seasonal watercourse that flows during and after the rainy season and then fragment into small water pools in the dry hot season that create temporary breeding sites.

The results of this study indicate that the melanic $A n$. arabiensis are likely to be the mosquitoes said to have adapted to survive as adults through nine months of severe drought and heat [41]. This suggestion is based on the exclusive presence of this form during the hottest and driest parts of the year, its relatively larger size and its heavy melanization. Larger individuals should have smaller surface/volume ratio and, therefore, have higher resistance for desiccation. Larger individuals should also have higher accumulation of glycogen and lipids and, therefore, are more likely to increase their metabolic body water during dry conditions [59]. Furthermore, a number of recent studies demonstrated that melanization plays a major role in insect desiccation resistance by decreasing the permeability of the cuticle to water [59-62].

In Drosophila melanogaster, body melanization is a quantitative trait and shows significant levels of both withinand between-population variation [63]. Geographical populations of $D$. melanogaster from Africa, India and Australia exhibit clinal variation in melanization, which suggest adaptations to local climatic conditions [61]. Increased melanization has been associated with higher fitness under thermal as well as aridity stresses in D. melanogaster, i.e. a darker cuticle may improve thermoregulation as well as reduce cuticlar water loss $[59,61,63]$. The extreme dry zone areas appear to form barriers to gene flow between and among permanent wet irrigated and temporary breeding sites of dry areas An. arabiensis populations.

This study provides the first evidence of a high level of phenotypic and genetic sub-structuring of An. arabiensis in Sudan. This finding may have important implications for the ecology of An. arabiensis and the epidemiology and control of malaria in Sudan and other dry lands in Africa. In future studies, it will be important to examine other molecular markers and conduct mating studies to determine the degree of speciation between the two forms. Furthermore it would be interesting to compare the vector competence of the two forms and examine their role in malaria transmission. An understanding of the mechanisms and genes related to physiological adaptation in $A n$. arabiensis may help explain how these mosquitoes survive through the dry season, and this in turn may help improve the control of malaria transmission in Sudan.

\section{Conclusions}

This study provides the first evidence of a high level of phenotypic and genetic sub-structuring of An. arabiensis populations in Sudan. Whether this genetic differentiation is an indication of recent speciation process or the presence of two species is unclear. Judging from the higher level of genetic variability in the melanic mosquitoes, it may be inferred that they experience less selection pressure and, therefore are better adapted to dry hot conditions of the collection sites, a phenomenon that has recently been recognized in other insect species. The marked difference between the two forms may have significant consequences for malaria transmission and its control in the region.

\section{Additional file}

Additional file 1: Polymorphic positions of mitochondrial DNA NAHD-dehydrogenase subunit 5 (ND5) gene in two forms of An. arabiensis collected from four collection sites (KS = Kassala, 
$\mathrm{KH}=$ Khartoum, GD = Gadaref, and NS = North State) with reference to the published mtDNA sequence (Beard et al. [51]; Gene Bank accession number L20934).

\section{Competing interests}

The authors declare that they have no competing interests.

\section{Authors' contributions}

MA conceived study ideas, conducted fieldwork, performed lab experiments, data analysis and wrote the manuscript. AM conducted fieldwork, performed laboratory work and conducted data analysis and helped in writing up. AV conducted laboratory work. FE helped in data interpretation. DAE conceived and designed study, conducted data analysis and helped in writing up of the manuscript. HT supervised study, conducted data analysis and helped in writing up of manuscript. All authors read and approved the final version of the manuscript.

\section{Acknowledgements}

Thanks are due to staff of Liverpool School of Tropical Medicine, El-Neelain Medical Centre, EINeelain University, University of Khartoum, for their help and support throughout this study. Many thanks are due to Dr. David Weatman whose comments helped improve the manuscript. The study was supported by a grant from the UNDP/World Bank/WHO Special Programme for Research and Training in Tropical Diseases for PhD study of Mariam Aboud at Liverpool School of Tropical Medicine and TDR/WHO Rentary grant (T16/181/635-A30894) for Mariam Aboud.

\section{Author details}

'Department of Biology, Faculty of Science and Technology, Al-Neelain University, Khartoum, Sudan. ${ }^{2}$ Department of Biotechnology, College of Applied and Industrial Sciences, University of Bahri, Khartoum, Sudan. ${ }^{3}$ Liverpool School of Tropical Medicine, Pembroke Place, Liverpool L3 5QA, UK. ${ }^{4}$ Department of Zoology, University of Khartoum, P.O. Box 321, Khartoum, Sudan. ${ }^{5}$ Department of Natural Sciences, University of Maryland Eastern Shore, 1 Backbone Rd, Princess Anne, MD 20851, USA.

Received: 15 June 2014 Accepted: 6 December 2014

Published: 13 December 2014

\section{References}

1. Harbach RE: The classification of genus Anopheles (Diptera: Culicidae): aworking hypothesis of phylogenetic relationships. Bull Entomol Res 2004, 94:537-553.

2. Sinka ME, Bangs MJ, Manquin S, Rubio-Palis Y, Chareonviriyaphap T, Coetzee M, Mbogo CM, Hemingway J, Patil AP, Temperley WH, Gething PW, Kabaria CW, Burkot TR, Harbach RE, Hay SI: A global map of dominant malaria vectors. Parasit Vectors 2012, 5:1-11.

3. Harbach RE: Mosquito Taxonomic Inventory. 2013. http://mosquito-taxonomicinventory.info/. accessed on 11 August 2014.

4. Davidson G: Anopheles gambiae: a complex of species. Bull World Health Organ 1964, 31:625-634.

5. Coetzee M, Hunt RH, Wilkerson R, Torre AD, Coullibaly M, Besansky NJ: Anopheles coluzzii and Anopheles amharicus, new members of the Anopheles gambiae complex. Zootaxa 2013, 3:246-274.

6. White GB: Anopheles bwambae sp. n., a malaria vector in the Semlik Valley, Uganda, and its relationship with other sibling species of the An. gambiae complex (Diptera: Culicidae). Syst Entomol 1985, 10:501-522.

7. Hunt RH, Coetzee M, Fettene M: The Anopheles gambiae complex: a new species from Ethiopia. Trans R SocTrop Med Hyg 1998, 92:231-235.

8. Coluzzi M, Sabatini A, Petrarca V, Di Deco MA: Chromosomal differentiation and adaptation to human environments in the Anopheles gambiae complex. Trans R Soc Trop Med Hyg 1979, 73:483-497.

9. Service M: Anopheles gambiae: Africa's principal malaria vector. Bull Entomol Soc Am 1985, 31:8-12.

10. Fontenille D, Lochouarn L, Diatta M, Sokhna C, Dia I, Diagne N, Lemasson JJ, Ba K, Tall A, Rogier C, Trape JF: Four years' entomological study of the transmission of seasonal malaria in Senegal and the bionomics of Anopheles gambiae and Anopheles arabiensis. Trans R Soc Trop Med Hyg 1997, 91:647-652.
11. Coetzee $M$, Craig M, le Sueur D: Distribution of African malaria mosquitoes belonging to the Anopheles gambiae complex. Parasitol Today 2000, 16:74-77.

12. Okello PE, Van Bortel W, Byaruhanga AM, Correwyn A, Roelants P, Talisuna A, D'Alessandro U, Coosemans M: Variation in malaria transmission intensity in seven sites throughout Uganda. Am J Trop Med Hyg 2006, 75:219-225.

13. Lindblade KA, Gimnig JE, Kamau L, Hawley WA, Odhiambo F, Olang G, Ter Kuile FO, Vulule JM, Slutsker L: Impact of sustained use of insecticide treated bed nets on malaria vector species distribution and culicine mosquitoes. J Med Entomol 2006, 43:428-432.

14. Bayoh MN, Mathias DK, Odiere MR, Mutuku FM, Kamau L, Gimnig JE, Vulule JM, Hawley WA, Hamel MJ, Walker ED: Anopheles gambiae: historical population decline associated with regional distribution of insecticide-treated bed nets in western Nyanza Province, Kenya. Malar J 2010, 9:62.

15. White GB: Anopheles gambiae complex and disease transmission in Africa. Trans R Soc Trop Med Hyg 1974, 68:278-301.

16. Service MW, Joshi GP, Radhan GD: A survey of Anopheles gambiae (species A) and An. arabiensis (species B) of the An. gambiae Giles complex in the Kisumu area of Kenya following insecticidal spraying with OMS-43 (Fenitrothion). Ann Trop Med Parasitol 1978, 72:377-386.

17. Mnzava AE, Mutinga MJ, Staak C: Host blood meals and chromosomal inversion polymorphism in Anopheles arabiensis in the Baringo District of Kenya. J Am Mosa Control Assoc 1994, 10:507-510.

18. Charlwood JD, Gassim M, Elnsur El, Donnelly M, Petrarca V, Billingsley PF, Pinto J, Smith T: The impact of indoor residual spraying with Malathion on malaria in refugee camps in eastern Sudan. Acta Trop 2001, 80:1-8.

19. Kent RJ, Mharakurwa S, Norris DE: Spatial and temporal genetic structure of Anopheles arabiensis in Southern Zambia over consecutive wet and drought years. Am J Trop Med Hyg 2007, 77:316-323.

20. Besansky NJ, Lehmann T, Fahey GT, Fontenille D, Lawrence E, Braack O, Hawley WA, Collins FH: Patterns of mitochondrial variation within and between African malaria vectors, Anopheles gambiae and Anopheles arabiensis, suggest extensive gene flow. Genetics 1997, 147:1817-1828.

21. Toure YT, Petrarca V, Traore SF, Coulibaly A, Maiga HM, Sankare O, Sow M, Di Deco MA, Coluzzi M: The distribution and inversion polymorphism of chromosomally recognized taxa of the Anopheles gambiae complex in Mali, West Africa. Parassitologia 1998, 40:477-511.

22. Donnelly MJ, Cuamba N, Charlwood JD, Collins FH, Townson H: Population structure in the malaria vector, Anopheles arabiensis Patton, in East Africa. Heredity 1999, 83:408-417.

23. Kamau L, Mukabana WR, Hawley WA: Analysis of genetic variability in Anopheles arabiensis and Anopheles gambiae using microsatellite loci. Insect Mol Biol 1999, 8:287-297.

24. Petrarca V, Nugud AD, Elkarim AM, Haridi AM, Dideco AM, Coluzzi M: Cytogenetic of the Anopheles gambiae complex in Sudan, with special reference to An. arabiensis: relationships with East and West African populations. Med Vet Entomol 2000, 14:149-164.

25. Simard F, Fontenille D, Lehmann T, Girod R, Brutus L, Gopaul R, Dournon C, Collins FH: High amounts of genetic differentiation between populations of the malaria vector Anopheles arabiensis from West Africa and Eastern outer Islands. Am J Trop Med Hyg 1999, 60:1000-1009.

26. Simard F, Lehmann T, Lemasson JJ, Diatta M, Didier F: Persistence of Anopheles arabiensis during the severe dry season conditions in Senegal: an in direct approach using microsatellite loci. Insect Mol Biol 2000, 9:467-479.

27. Gentile G, della Torre A, Maegga B, Powell JR, Caccone A: Genetic differentiation in the African malaria Vector, Anopheles gambiae s.s., and the problem of taxonomic status. Genetics 2002, 161:1561-1578.

28. Donnelly MJ, Townson H: Evidence for extensive genetic differentiation among populations of the malaria vector Anopheles arabiensis in Eastern Africa. Insect Mol Biol 2000, 9:357-367.

29. Donnelly MJ, Monica CL, Lehmann T: Evidence for recent population expansion in the evolutionary history of the malaria vectors Anopheles arabiensis and Anopheles gambiae. Mol Biol Evol 2001, 18:1353-1364.

30. Onyabe DY, Conn JE: Population genetic structure of the malaria mosquito An. arabiensis across Nigeria suggests range expansion. Mol Ecol 2001, 10:2577-2591.

31. Nyanjom SR, Chen H, Gebre-Michael T, Bekele E, Shililu J, Githure J, Beier JC, Yan G: Population genetic structure of Anopheles arabiensis mosquitoes in Ethiopia and Eritrea. Heredity J 2013, 94:457-463.

32. Donnelly MJ, Pinto J, Girod R, Besansky NJ, Lehmann T: Revisiting the role of introgression vs shared ancestral polymorphisms as key processes 
shaping genetic diversity in the recently separated sibling species of the Anopheles gambiae complex. Heredity 2004, 92:61-68.

33. Morlais I, Girod R, Hunt R, Simard F, Fontenille D: Population structure of Anopheles arabiensis on La Reunion Island, Indian Ocean. Am J Trop Med Hyg 2005, 73:1077-1082.

34. Temu EA, Yan G: Microsatellite and mitochondrial genetic differentiation of Anopheles arabiensis (Diptera: Culicidae) from western Kenya, the Great Rift Valley, and coastal Kenya. Am J Trop Med Hyg 2005, 73:726-733.

35. Tripet F, Dolo G, Lanzaro GC: Multilevel analyses of genetic differentiation in Anopheles gambiae s.s. reveal patterns of gene flow important for malaria-fighting mosquito projects. Genetics 2005, 169:313-324.

36. Lee Y, Seifert SN, Fornadel M, Norris DE, Lanzaro GC: Single-nucleotide polymorphisms for high-throughput genotyping of Anopheles arabiensis in East and Southern Africa. J Med Entomol 2012, 49:307-315.

37. Abuelmaali SA, Elaagip AH, Basheer MA, Frah EA, Ahmed FT, Elhaj HF, Seidahmed OM, Weetman D, Mahdi Abdel Hamid M: Impacts of agricultural practices on insecticide resistance in the malaria vector Anopheles arabiensis in Khartoum State. Sudan PLoS One 2013, 8:e80549.

38. Musa MI, Shohaimi S, Hashim NR, Krishnarajah I: A climate distribution model of malaria transmission in Sudan. Geospat Health 2012, 7:27-36.

39. Noor AM, EIMardi KA, Abdelgader TM, Patil AP, Amine AA, Bakhiet S Mukhtar MM, Snow RW: Malaria Risk Mapping for Control in the Republic of Sudan. Am J Trop Med Hyg 2012, 87:1012-1021.

40. Omer SM, Cloudsley-Thompson JL: Dry season biology of Anopheles gambiae Giles in the Sudan. Nature 1968, 217:879-880

41. Omer SM, Cloudsley-Thompson JL: Survival of female Anopheles gambiae Giles through a 9-month dry season in Sudan. Bull World Health Organ 1970, 42:319-330

42. Lehmann T, Dao A, Yaro AS, Adamou A, Kassogué Y, Diallo M, Sékou T, Coscaron-Arias C: Aestivation of the African malaria mosquito, Anopheles gambiae in the Sahel. Am J Trop Med Hyg 2010, 83:601-606.

43. Adamou A, Dao A, Timbine S, Kassogué Y, Yaro AS, Diallo M, Traoré SF, Huestis DL, Lehmann T: The contribution of aestivating mosquitoes to the persistence of Anopheles gambiae in the Sahel. Malar J 2011, 10:151.

44. Yaro AS, Traoré Al, Huestis DL, Adamou A, Timbiné S, Kassogué Y, Diallo M, Dao A, Traoré SF, Lehmann T: Dry season reproductive depression of Anopheles gambiae in the Sahel. J Insect Physiol 2012, 58:1050-1059.

45. Huestis DL, Yaro AS, Traoré Al, Dieter KL, Nwagbara Jl, Bowie AC, Adamou A, Kassogué Y, Diallo M, Timbiné S, Dao A, Lehmann T: Seasonal variation in metabolic rate, flight activity and body size of Anopheles gambiae in the Sahel. J Exp Biol 2013, 215:2013-2021.

46. Lehmann T, Dao A, Yaro AS, Diallo M, Timbiné S, Huestis DL, Adamou A, Kassogué Y, Traoré Al: Seasonal variation in spatial distributions of Anopheles gambiae in a Sahelian village: evidence for aestivation. $J$ Med Entomol 2014, 51:27-38.

47. Gillies MT, De Meillon B: The Anophelinae of Africa south of the Sahara (Ethiopian Zoogeographical Region). In Publications of The South African Institute for Medical Research, no.54. 2nd edition. Johannesburg: South African Institute for Medical Research; 1968.

48. Gillies MT, Cotezee M: A supplement to the Anophelinae of Africa South of the Sahara. In Publications of The South African Institute for Medical Research, no.55. Johannesburg: (Afrotropical Region). South African Institute for Medical Research; 1987.

49. Scott JA, Brogdon WG, Collins FH: Identification of single specimens of the Anopheles gambiae complex by the polymerase chain reaction. Am J Trop Med Hyg 1993, 49:520-529.

50. Ballinger-Crabtree ME, Black WCV, Miller BR: Use of genetic polymorphism detected by the Random-Amplified Polymorphic DNA Polymerase Chain Reaction (RAPD-PCR) for differentiation and identification of Aedes aegypti subspecies and populations. Am J of Trop Med Hyg 1992, 47:893-901.

51. Beard CB, Hamm DM, Collins FH: The mitochondrial genome of the mosquito Anopheles gambiae: DNA sequence, genome organization, and comparisons with mitochondrial sequences of other insects. Insect Mol Biol 1993, 2:103-124.

52. Rozas J, Rozas R: DnaSP version 3.5: an integrated program for molecular population genetics and molecular evolution analysis. Bioinformatics 1999, 15:174-175.

53. Tajima F: Statistical method for testing the neutral mutation hypothesis by DNA polymorphism. Genetics 1989, 123:585-595.
54. Fu YX, Li WH: Statistical tests of neutrality of mutations. Genetics 1993, 143:1313-1320

55. Clement M, Posada D, Crandall KA: TCS: a computer program to estimate gene genealogies. Mol Ecol 2000, 9:1657-1659.

56. Templeton AR, Crandall KA, Sing CF: A cladistic analysis of phenotypic associations with haplotypes inferred from restriction endonuclease mapping and DNA sequence data. III. Cladogram estimation. Genetics 1992, 132:619-633.

57. Crandall KA, Templeton AR: Empirical tests of some predictions from coalescent theory with applications to intraspecific phylogeny reconstruction. Genetics 1993, 134:959-969.

58. Lehmann T, Hawley WA, Grebert H, Collins FH: The effective population size of Anopheles gambiae in Kenya: implications for population structure. Mol Biol Evol 1998, 15:264-276.

59. Hoffman AA: Acclimation for desiccation resistance in drosophila melanogaster and the association between acclimation responses and genetic variation. J Insect Physiol 1990, 36:885-891.

60. True JR: Insect melanism: the molecules matter. Trends Ecol Evol 2003, 18:640-647.

61. Ramniwas S, Kajla B, Dev K, Parkash R: Direct and correlated responses to laboratory selection for body melanisation in Drosophila melanogaster: support for the melanisation-desiccation resistance hypothesis. J Exp Biol 2013, 216:1244-1254.

62. Aggarwal DD, Ranga P, Kalra B, Parkash R, Rashkovetsky E, Bantis LE: Rapid effects of humidity acclimation on stress resistance in Drosophila melanogaster. Comp Biochem Physiol A Mol Integr Physiol 2013, 166:81-90

63. Parkash R, Kalra B, Sharma V: Changes in cuticular lipids, water loss and desiccation resistance in a tropical drosophilid: analysis of variation between and within populations. Fly 2008, 2:189-197.

64. Donnelly MJ, Simard F, Lehman T: Evolutionary studies of malaria vectors. Trends Parasitol 2002, 18:75-80

doi:10.1186/1475-2875-13-492

Cite this article as: Aboud et al:: A genotypically distinct, melanic variant of Anopheles arabiensis in Sudan is associated with arid environments. Malaria Journal 2014 13:492.

\section{Submit your next manuscript to BioMed Central and take full advantage of:}

- Convenient online submission

- Thorough peer review

- No space constraints or color figure charges

- Immediate publication on acceptance

- Inclusion in PubMed, CAS, Scopus and Google Scholar

- Research which is freely available for redistribution 